\title{
Relationship Between Target Delineation and Surface Dose in Breast Radiotherapy Using Helical Tomotherapy
}

\author{
Suheyla Aytac ARSLAN ${ }^{1}$, Gonca Altinisik INAN², Ipek Pinar ARAL ${ }^{2}$, Selcan CELIK ${ }^{2}$, \\ Havva KARABUGA ${ }^{2}$, H. Furkan OZTURK ${ }^{2}$ \\ ${ }^{1}$ Yildirim Beyazit University, Faculty of Medicine, Department of Radiation Oncology \\ ${ }^{2}$ Atatürk Eğitim Araştırma Hastanesi, Department of Radiation Oncology, Ankara, TURKEY
}

\begin{abstract}
To investigate the effect of different planning target volumes (PTVs) and the breathing motion on the surface dose with Helical Tomotherapy (HT). Irradiations with different target volumes (PTV-3, PTVO, PTV+5) using a male randophantom placed on a dynamic platform were performed and measured with MOSFET. The irradiation of the phantom on the dynamic platform revealed that at least $75 \%$, $91 \%$ and $104 \%$ of the predicted surface dose obtained for PTV-3, PTV 0 and PTV+5, respectively. Statistically significant difference was observed between static and dynamic measurements for PTV-3 $(p=0.02)$. Surface dose was decreased with increased breathing frequency and amplitude for PTV 0 without statistical significance. HT enables an effective surface dose in chest wall radiotherapy irrespective of the respiratory movement. The delineation is an important aspect of superficial moving targets such as chest wall in treatment with HT. The effect of breathing motion on surface dose is observed most obviously on cropped PTVs.
\end{abstract}

Keywords: Delineation, Surface dose, Breast cancer, Helical Tomotherapy, Breathing

ÖZET

Meme Radyoterapisinde Tomoterapi ile Yüzey Dozu ve Konturlama ilişskisi

Helikal tomoterapi (HT) ile göğüs duvarı ışınlamasında, farklı planlama hedef hacimlerinin (PTV'ler) ve solunum hareketinin yüzey dozu üzerindeki etkisini araştırmak. Dinamik bir platform üzerine yerleştirilen bir erkek randofantom kullanılarak farklı hedef hacimlerde (PTV-3, PTVO, PTV+5) ışınlamalar yapıldı ve bunlar Mosfet ile ölçüldü. Dinamik fantom kurgusu ile yapılan ışınlama sırasıyla PTV-3, PTVO ve PTV+5 için öngörülen yüzey dozunun en az \%75, \%91 ve\% 104'ünün elde edildiğini ortaya koymuştur. PTV-3 için statik ve dinamik ölçümler arasında istatistiksel olarak anlamlı fark bulundu ( $(=0.02)$. Yüzey dozu, PTVO için artmış solunum frekansı ve genliği ile istatistiksel olarak anlamsız bir azalma gösterdi. HT göğüs duvarı radyoterapisinde solunum hareketinden bağımsız olarak etkili bir yüzey dozuna olanak tanır. Konturlama, HT ile tedavide göğüs duvarı gibi yüzeysel hareketli hedefler açısından önemlidir. Hareket etkisi en belirgin olarak traşlanmış PTV'de gözlenir.

Anahtar Kelimeler: Konturlama, Yüzey dozu, Göğüs duvarı, Helikal tomoterapi, Solunum 


\section{INTRODUCTION}

Breast cancer is the most common form of cancer in women in both the developed and developing world, and the estimated number of deaths from breast cancer is over 600.000 worldwide in $2018 .{ }^{1}$ Adjuvant radiotherapy (RT) is generally offered to the breast cancer patients as a part of curative management and it has shown benefits in terms of locoregional control and long-term survival. ${ }^{2}$

Surface doses have always been an important factor associated with the probability of local control and skin toxicity in breast cancer RT. Dermal lymphatics located 1-5 mm below the surface considered as high-risk area likely to contain cancer cells. Therefore, adequate dosing of this area is critically important and necessitates bolus use for some time during $\mathrm{RT}^{3-5}$, however related excessive toxicity must be considered. ${ }^{6}$

Intensity-modulated radiotherapy (IMRT) has some dosimetric advantages, both improving dose homogeneity and conformity within the target volume and reducing doses to organs at risk, which makes it a favorable option for the adjuvant treatment of breast cancer ${ }^{7-10}$ although long term clinical results are scarce. ${ }^{11}$ Helical TomoTherapy (HT, Accuray Tomotherapy Hi-Art) is an effective and frequently employed IMRT option ${ }^{12}$ and it provides an advantage in adequate dosing of superficial targets. ${ }^{13,14}$

The purpose of this study is to investigate the surface dose of HT with different planning target volume (PTV) delineations by using a customized male anthropomorphic phantom on a dynamic platform simulating breathing.

\section{METHODS}

\section{Dynamic Platform:}

A wooden platform designed to mimic dorsoventral chest wall movements during breathing was manufactured. Platform's frequencies and amplitudes set up to $12-18$ breaths/min and 3-5 $\mathrm{mm}$ respectively. Static and dynamic measurements with 3 different PTVs performed to see the relationship between PTV delineation and breathing.

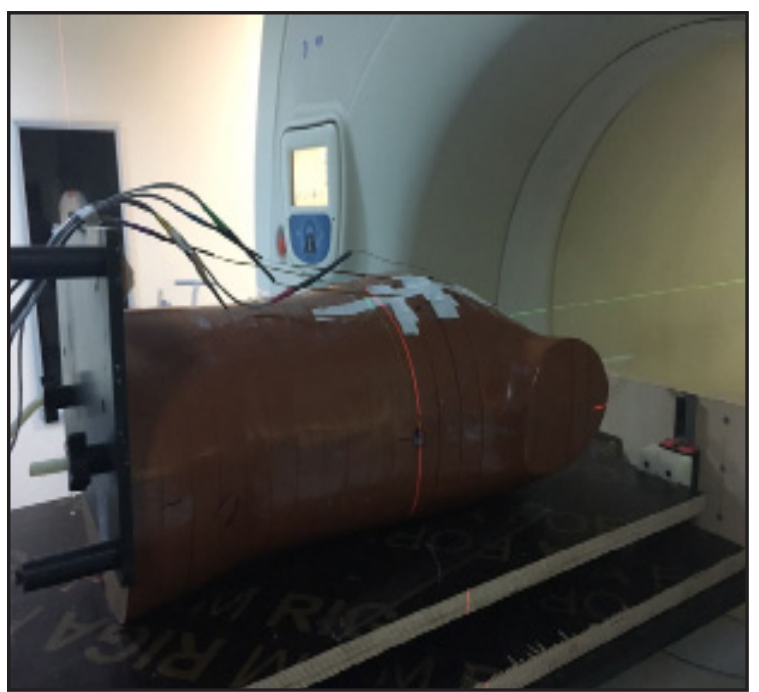

Figure 1. Delineation for PTVO

\section{Computed Tomography (CT) Simulation, Con- touring, Plan and Irradiation:}

A male phantom was placed on the platform and scanned at a 3-mm slice thickness with spiral CT (Toshiba, Aquilon Lb, V6.0-16 detectors). Hypothetical clinical target volumes (CTVs) and organs at risk such as lungs, heart and contralateral breast were contoured. PTVs were generated using these CTVs and the external body contour (EBC) as a guide (Figure 1). Three different PTVs were generated: for PTV-3; the surface margin was created via a 3-mm crop from the EBC, for PTV0; the surface margin was reclined on the EBC. Finally, PTV+5 was formed with an expansion of $5 \mathrm{~mm}$ from the EBC to mimic 5-mm bolus. Depending on 3 different PTVs, a prescribed dose of $200 \mathrm{cGy}$ to the 95\% isodose line was planned with HT planning software (Figure 2). Normal calculation resolution grid was used with a field width of $2.5 \mathrm{~cm}$, a modulation factor of 2 and a pitch of 0.3. Irradiations were done according to these plans under static and 4 dynamic conditions (12 and 18 breaths/min with 3 and $5 \mathrm{~mm}$ amplitude). A 5-mm bolus was placed on the phantom for PTV+5. A mobile metal oxide semiconductor field-effect transistor (MOSFET) probes were placed at 4 different points with respect to green lasers (Figure 3). 

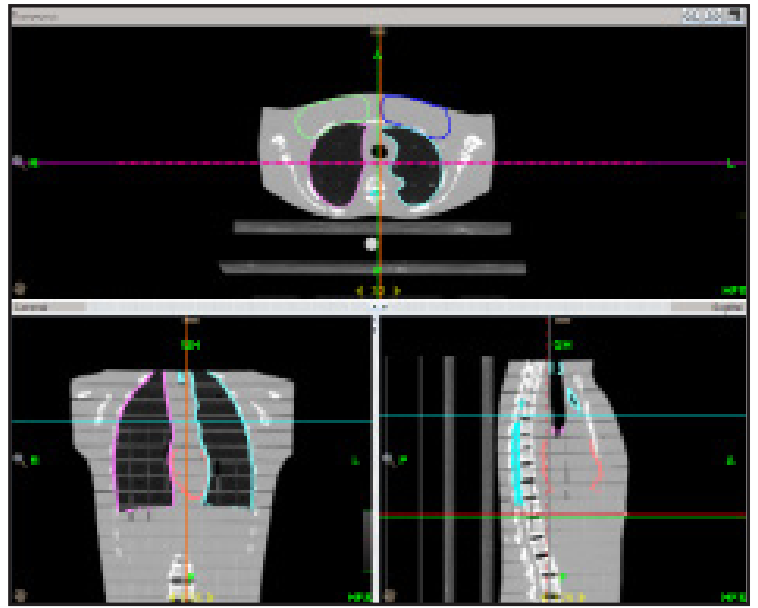

Figure 2. Dose painting for PTV-3.

Surface doses of the MOSFET points on phantom were measured for each of the deliveries and recorded. So; for all 5 set up, irradiations with HT and measurements with MOSFET were repeated. Mean surface doses of these predefined points with static and dynamic phantom setup were compared with each other and the calculations from Treatment Planning System (TPS) with respect to prescribed dose.

\section{MOSFET:}

A mobile metal oxide semiconductor field-effect transistor (MOSFET) TN-RD-16 wireless dose verification system (Thomson \& Nielsen Electronics, now Best Medical Canada, Nepean, Ontario, Canada) was used for dose measurements. The basic structure of MOSFET was described by Soubra et al. ${ }^{15}$ Calibration of the MOSFET against an ion chamber was performed using the HT unit in a stationary mode since the difference between static and rotational beam calibration coefficient is negligible. ${ }^{16}$ Ion chamber was positioned at a depth of $1.6 \mathrm{~cm}$ in a solid water phantom. The calibrations were done with a source to source distance (SSD) of $80 \mathrm{~cm}$ at a field size of $5 \times 40 \mathrm{~cm}^{2}$. A dose of 200 cGy was delivered to the detector and this process was repeated three times for each calibration. The MOSFET readings differed from the ion chamber readings by $1.23 \% \pm 2.4$, which is within the manu-

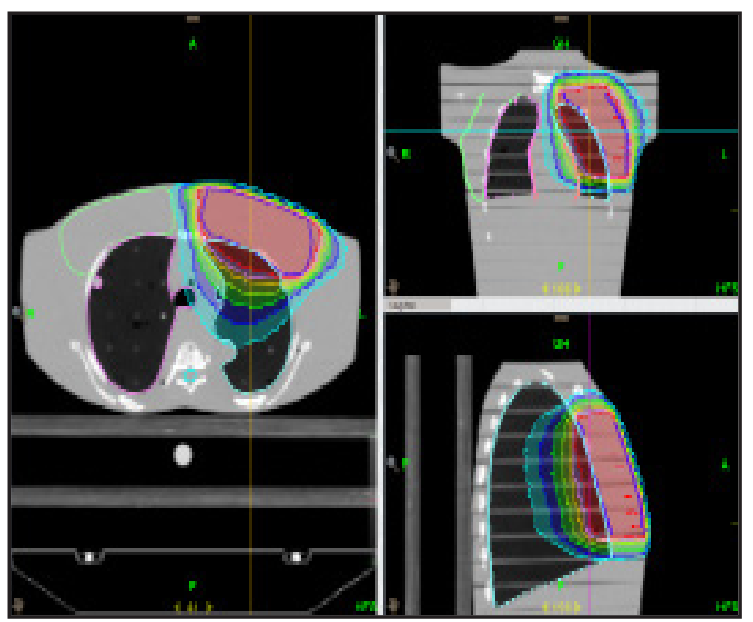

Figure 3. Male phantom placed on the board, which was used to simulate breathing movements. There is no radiation interference up to $70 \mathrm{~cm}$.

facturer's specification of $2 \%$ at the 200 cGy dose level at a standard bias.

MOSFET dosimetry is a reliable method for dose verification associated with external beam radiotherapy. This technology was used in the current study because of the relatively small size of the dosimeter, its practical handling and its ability to provide immediate results. ${ }^{17}$

\section{Statistical Analysis}

SPSS version 20 was used for statistical analysis. Mean TPS calculations and measurements of 4 predefined points and standard error (se) of mean were obtained. Mann-Whitney U test used for comparison between groups.

\section{RESULTS}

The average (mean \pm standard error) static and dynamic measurements with 5 different setups for PTV-3, PTV0 and PTV+5 are shown in Table 1.

For PTV-3, the calculations showed a mean surface dose of $182 \pm 4.9 \mathrm{cGy}$ at the predetermined points. The mean static MOSFET measurements at these points were $159.3 \pm 1.4 \mathrm{cGy}$ with a difference of $12.3 \%$ and $20.5 \%$ compared with calculations and prescribed dose respectively. The mean dynamic measurements were $150 \pm 0.8,151 \pm$ 
Table 1. TPS Calculations and MOSFET measurements

\begin{tabular}{|c|c|c|c|c|c|c|c|}
\hline & \multirow{2}{*}{$\begin{array}{c}\text { TPS } \\
\text { Calculations }\end{array}$} & \multicolumn{5}{|c|}{ MOSFET Measurements } & \multirow[b]{2}{*}{$\begin{array}{l}\text { Static vs Dynamic } \\
\mathrm{p}\end{array}$} \\
\hline & & No motion & $\begin{array}{l}12 \mathrm{brt} / \mathrm{min} \\
3 \mathrm{~mm}\end{array}$ & $\begin{array}{l}18 \mathrm{brt} / \mathrm{min} \\
3 \mathrm{~mm}\end{array}$ & $\begin{array}{l}12 \mathrm{brt} / \mathrm{min} \\
5 \mathrm{~mm}\end{array}$ & $\begin{array}{l}18 \mathrm{brt} / \mathrm{min} \\
5 \mathrm{~mm}\end{array}$ & \\
\hline PTV-3 & $182 \pm 4.9$ & $159.3 \pm 1.4$ & $157 \pm 1.1$ & $152 \pm 1.1$ & $150 \pm 0.8$ & $151 \pm 1.4$ & $0.02^{*}$ \\
\hline PTV 0 & $201 \pm 3$ & $186 \pm 2.8$ & $186.7 \pm 2.2$ & $185.2 \pm 2.2$ & $185.2 \pm 1.1$ & $182.5 \pm 2.1$ & 0.92 \\
\hline $\mathrm{PTV}+5$ & $207 \pm 1.9$ & $210 \pm 0.8$ & $208 \pm 4.9$ & $213 \pm 1.7$ & $209.3 \pm 0.3$ & $208 \pm 1.5$ & 0.65 \\
\hline
\end{tabular}

Abbreviations: PTV= Planning Target Volume; brt= Breaths

$1.4 \mathrm{cGy}, 152 \pm 1.1 \mathrm{cGy}$ and $157 \pm 1.2 \mathrm{cGy}$ with different breathing simulations (at least $75 \%$ of the prescribed dose). Deviations between static and dynamic measurements were approximately 5\% and there was statistically significant difference between them $(p=0.02)$. For PTV0, the calculated mean surface dose of $201 \pm 3.1$ cGy was achieved for the prescribed dose of $200 \mathrm{cGy}$, and the mean static MOSFET measurement was $186 \pm 2.8 \mathrm{cGy}$. The mean dynamic measurements of $186.7 \pm 2.2$ cGy, $185.2 \pm 1.1 \mathrm{cGy}, 185.2 \pm 2.2 \mathrm{cGy}$ and $182.5 \pm 2.1$ cGy are obtained and corresponded to the at least 91\% of prescribed dose. Surface measurements were inversely proportional with breathing frequency and amplitude such that surface dose decreased with increased amplitude and frequency. For PTV+5, the calculated mean surface dose was $207 \pm 1.9 \mathrm{cGy}$, the static and dynamic MOSFET measurements were $210 \pm 0.8 \mathrm{cGy}, 208 \pm 4.9 \mathrm{cGy}$, $213 \pm 1.7 \mathrm{cGy}, 209.3 \pm 0.3 \mathrm{cGy}$ and $208 \pm 1.5$ cGy respectively. Deviations between static and dynamic measurements were $1.5 \%$ and no statistically significant difference was observed between them.

\section{DISCUSSION}

This study aims to analyze the surface dose of the HT with varying PTV generations and the effect of breathing motion on it. During tidal breathing, chest wall displacements occur in the $\mathrm{x}, \mathrm{y}$ and $\mathrm{z}$ directions; these displacements are related to age, sex, posture and location. The largest movement occurs in the dorsoventral direction (3-5 $\mathrm{mm})$ and increases with deep breathing. ${ }^{18} \mathrm{~A}$ dynamic platform was used to simulate dorsoventral chest wall movements and the measurements were done with MOSFET dosimetry. The respiratory rate for adults is 12-18 breaths/minute. In the present study, the dynamic phantom setup was designed according to the extremes of dorsoventral breathing movements in terms of amplitude and frequency, though less dose deviations in tidal breathing could be expected.

A surface dose of at least $75 \%, 91 \%$ and $104 \%$ of prescribed dose was obtained under dynamic phantom set up with PTV-3, PTV0 and PTV +5 respectively. Statistically significant difference between static and dynamic measurements was observed with PTV-3. Surface dose was decreased with increased breathing frequency and amplitude for PTV0.

The results of present study are consistent with several published reports showing that the majority of applications of HT planning software overestimate the superficial dose by up to $2.5-10 \%$, which is an important consideration, especially when evaluating the surface dose in chest wall treatment. ${ }^{13,14} \mathrm{In}$ the present study, the most evident deviation between TPS calculations and measurements (static and dynamic) was seen for PTV-3: the mean surface measurements were approximately $13.8 \%$ to $17.6 \%$ lower than the mean calculated TPS dose. These values were in the range of $7.5 \%$ to $9.5 \%$ with PTV0, which is more compatible. On the contrary, for PTV +5 measured doses were slightly higher than TPS calculation.

Compared to the static measurements, motion contributed approximately $2-5 \%$ to estimations, this effect was most obvious with PTV-3 which result- 
ed a statistically significant difference on surface dose for static versus dynamic measurements. It can be speculated that skin-sparing effect of HT with cropped PTVs deepens by motion. Lower surface doses obtained with dynamic measurements were correlated with frequency and amplitude in PTV0 but not with PTV-3. Higher doses obtained with PTV+5 can be attributed to the 3-6\% reliability of the MOSFET for depth dose measurement with a 5 -mm bolus. Static and dynamic measurements exhibited a $99.5 \%$ correlation demonstrating a relatively more homogeneous dose distribution in deep layers with HT under tidal breathing.

Ramsey et al. analyzed the surface dose of HT with Termoluminence Dosimeter (TLD) placed on a head-neck phantom for target volumes of cropped PTVs ranging from 1-5 mm for a 2 Gy prescribed dose without interference of motion. For PTV0, an average dose of $1.73 \pm 0.1 \mathrm{~Gy}$ ( $\approx 86.6 \%$ of prescribed dose) for PTV-3, an average dose of $1.45 \pm 0.03$ $(\approx 72.5 \%$ of the prescribed dose) was measured. This data corresponds to the average dose of $92 \%$ and $79 \%$ obtained with static measurements of our study. ${ }^{14}$

Javedan et al. studied the surface dose on a male phantom without emphasize on PTV contouring. Measurements were done with MOSFET and a dose of $152.4 \pm 6.1 \mathrm{cGy}(\approx 76 \%)$ and $205.6 \pm 9.7$ cGy $(\approx 102 \%)$ were obtained on surface and under a $5 \mathrm{~mm}$ bolus for a 200 cGy prescription, which fits quite well to our PTV-3 and PTV+5 measurements. ${ }^{19}$

In a similar study of surface dose measurements with TLD chips and transvers direction moving phantom, the researchers found a dose of 1.39 to $1.43 \mathrm{~Gy}$ for a $4.2 \mathrm{~mm}$ and 1.44 to $1.45 \mathrm{~Gy}$ for a $1.4 \mathrm{~mm}$ amplitude with varying breathing frequencies (10-15-20 / $\mathrm{min})$ per 1.8 Gy prescription for PTVskin. ${ }^{20}$ In this phantom setup a maximal $3.8 \%$ deviation was observed between measurements which is below the $5 \%$ measurement uncertainty of the TLDs. Since there is no randomness in this breathing simulation, it is likely that measurement errors with in-vivo random breathing will be less, the authors interpreted. They also found an average $17 \%$ difference between calculations and measurements.
It has been shown that IMRT markedly reduces dose inhomogeneity to the breast compared to conventional techniques, thus demonstrating a successful reduction in radiation-related acute dermal toxicity. ${ }^{8}$ Toxicity increases with cumulative radiation dose; erythema is common after a skin dose of approximately 3000 cGy. Moist desquamation occurs when doses to the skin exceed $5000 \mathrm{cGy} .{ }^{21}$ Dynamic phantom setup revealed a minimum of $75 \%, 91 \%$ and $104 \%$ of prescribed dose for PTV3, PTV0 and PTV+5 generations respectively. Accordingly, PTVs can be determined according to the clinical situation i.e. the risk status of the outermost region which depends on the extent of tumor, type of surgery etc. Surface dose deficiency was most evident for PTV-3; for a prescribed dose of $200 \mathrm{cGy}$, a mean dose of approximately 150.5 - 157 cGy was measured which is inadequate in the case of chest wall RT. PTV-3 may be appropriate for RT after breast conserving surgery whereas skin is mostly not a target at risk since skin-sparing mastectomies are generally considered oncologically safe with LR rates comparable to those of conventional mastectomy. ${ }^{22}$ Thus, in addition to the dose homogeneity achieved by HT planning, a 3-mm extraction from the EBC will further protect the skin from excessive toxicity without jeopardizing the local control. On the other hand, adequate surface dosing is much more important after postmastectomy and recurrent chest wall RT, so that PTV generations of 0 margin could provide a substantial portion (90-94\%) of the dose to the skin of the chest wall during tidal breathing.

Surface dose measurements can vary depending on the measurement system and the MOSFET itself..$^{23-25}$ One limitation of the current study is that the measurements were not confirmed by other dosimetry techniques. Another limitation is the designed board system. The board is assumed to mimic breathing but moves only in the $\mathrm{z}$ direction at certain frequencies, whereas true breathing involves motion of the chest wall in the $\mathrm{x}, \mathrm{y}$, and $\mathrm{z}$ directions, and the amount of displacement changes for different locations. ${ }^{18}$ Additionally, we performed measurements for only 4 points, which is quite low, and increasing the number of points would increase the accuracy definitely. In a study by Richter A. et al. the motion amplitude of breast 
measured in the 4D CT images was between 0.2 and $3.8 \mathrm{~mm}, 1.8 \mathrm{~mm}$ on average ${ }^{26}$ which is much lower than the amplitudes we choose in our measurements. So, considering the sophisticated nature of the HT irradiation algorithm, it would be desirable to confirm these measurements in vivo.

\section{Conclusions}

HT enables an effective surface dose in the radiotherapy of breast cancer during breathing. Delineation is an important aspect of superficial moving targets such as chest wall or breast. The effect of motion is most obvious on cropped PTV.

\section{REFERENCES}

1. Bray F, Ferlay J, Soerjomataram I, et al. Global Cancer Statistics 2018: GLOBOCAN Estimates of Incidence and Mortality Worldwide for 36 Cancers in 185 Countries. CA Cancer J Clin 68: 394-424, 2018.

2. Clarke M, Collins R, Darby S, et al. Effects of radiotherapy and of differences in the extent of surgery for early breast cancer on local recurrence and 15-year survival: an overview of the randomized trials. Lancet 366: 2087-106, 2005

3. Buchanan CL, Dorn PL, Fey J, et al. Locoregional recurrence after mastectomy: Incidence and Outcomes. Am Coll Surg 203: 469-474, 2006

4. Mayadev J, Einck J, Elson S, et al. Practice patterns in the delivery of radiation therapy after mastectomy among the University of California Athena Breast Health Network. Clin Breast Cancer 15: 43-47, 2015.

5. Blitzblau RC, Horton JK. Treatment planning technique in patients receiving postmastectomy radiation therapy. Pract Radiat Oncol 3: 241-248, 2013.

6. Pignol JP, Vu TT, Mitera G, et al. Prospective evaluation of severe skin toxicity and pain during postmastectomy radiation therapy. Int J Radiat Oncol Biol Phys 91: 157-164, 2015.

7. Ekici K, Gokce T, Karadogan I, et al. Is helical tomotherapybased intensity-modulated radiotherapy feasible and effective in bilateral synchronous breast cancer? A two-center experience. J BUON 21(1),46-52, 2016.

8. Pignol JP, Olivotto I, Rakovitch E, et al. A multicenter randomized trial of breast intensity-modulated radiation therapy to reduce acute radiation dermatitis. J Clin Oncol 26: 20852092, 2008

9. Dogan N, Cuttino L, Lloyd R, et al. Optimized dose coverage of regional lymph nodes in breast cancer: the role of inten- sity-modulated radiotherapy. Int J Radiat Oncol Biol Phys 68:1238-1250, 2007.

10. Barnett GC, Wilkinson JS, Moody AM, et al. Randomized controlled trial of forward-planned intensity-modulated radiotherapy for early breast cancer: interim results at 2 years. Int J Radiat Oncol Biol Phys 82: 715-723, 2011.

11. Buwenge M, Cammelli S, Ammendolia I, et al. Intensity modulated radiation therapy for breast cancer: current perspectives. Breast Cancer (Dove Med Press) 9: 121-126, 2017

12. Cendales R, Schiappacasse L, Schnitman F, et al. Helical tomotherapy in patients with breast cancer and complex treatment volumes. Clin Transl Oncol 13: 268-274, 2011.

13. Cheek D, Gibbons JP, Rosen II, Hogstrom KR. Accuracy of TomoTherapy treatments for superficial target volumes. Med Phys 35: 3565-3573, 2008.

14. Ramsey CR, Seibert RM, Robison B, Mitchell M. Tomotherapy superficial dose measurements. Helical Med Phys 34: 3286-3293, 2007

15. Saubra M, Cygler J, Mackay G. Evaluation of a dual bias dual metal oxide-silicon semiconductor field effect transistor detector as radiation dosimeter. Med Phys 21: 567-572, 1994.

16. Kinhikar RA, Murthy V, Goel V, et al. Skin dose measurements using MOSFET and TLD for head and neck patients treated with tomotherapy. Applied Radiation and Isotopes 67:1683-1685, 2009

17. Butson MJ, Rozenfeld A, Mathur JN, et al. A new radiotherapy surface dose detector: The MOSFET. Med. Phys 23: 655658,1996

18. Wantier M, Cheron G, Estenne M, et al. Chest wall motion during tidal breathing. J Appl Physiol (1985); 83: 1531-1537, 1997.

19. Javedan K, Zhang G, Mueller R, et al. Skin dose study of chest wall treatment with tomotherapy. Jpn J Radiol 27: 355362, 2009.

20. Zibold F, Sterzing F, Sroka-Perez G, et al. Surface Dose in the Treatment of Breast Cancer with Helical Tomotherapy. Strahlenkter Oncol 185: 574-581, 2009.

21. Uschold GM. Breast cancer. Principles and practice of radiation therapy. In: Charles M, Dennis T, (Eds.), St. Louis, Mosby; 2004; 843-874.

22. Kroll SS, Khoo A, Singletary SE, et al. Local recurrence risk after skinsparing and conventional mastectomy: a 6-year follow-up. Plast Reconstr Surg 104: 421-425, 1999.

23. Hardcastle N, Soisson E, Metcalfe P, et al. Dosimetric verification of helical tomotherapy for total scalp irradiation. Med Phys 35: 5061-5068, 2008.

24. Quach KY, Morales J, Butson MJ, et al. Measurement of radiotherapy $\mathrm{x}$-ray skin dose on a chest wall phantom. Med Phys 27: 1676-1680, 2000. 
25. Xiang HF, Song JS, Chin DW, et al. Build-up and surface dose measurements on phantoms using micro-MOSFET in 6 and $10 \mathrm{MV} \mathrm{x}$-ray beams and comparisons with Monte Carlo calculations. Med Phys 34: 1266-1273, 2007.

26. Richter A., Sweeney R, Baier K, et al. Effect of breathing motion in radiotherapy of breast cancer. Strahlenkter Oncol 185: 425-430, 2009.

\section{Correspondence:}

\section{Dr. Suheyla Aytac ARSLAN}

Yıldırım Beyazıt Üniversitesi

Radyasyon Onkolojisi Anabilim Dalı

Ankara Ataturk Araştırma ve Eğitim Hastanesi

06800 Bilkent 1. Cadde

ANKARA / TURKEY

Tel: (+90-312) 2912525

Fax: (+90-312) 2912525

e-mail: saytac1@gmail.com 